\title{
Mass Screening of Temperate Fruit Germplasm against Major Viruses for developing a 'Clean Stock' Programme in Himachal Pradesh, India
}

\author{
Anil Handa* and Shelly Kapoor
}

Plant Virology Laboratory, Dr. Y S Parmar University of Horticulture and Forestry, Nauni-173230, Solan, Himachal Pradesh, India

*Corresponding author

\section{A B S T R A C T}

\section{Keywords}

Mass screening,

Temperate, Major

viruses, Clean stock

Article Info

Accepted:

04 May 2018

Available Online:

10 June 2018
The importance of viruses and related pathogens on the quality of planting material is largely recognised as a major component in a certification protocol aimed at developing 'Clean Stock' programme. Since majority of the viruses associated with temperate fruits are of latent nature, the significance of a quick and reliable method for early detection of these viruses is of paramount importance. This paper discusses the use of DAS-ELISA as an efficient tool for the detection of major viruses of temperate fruit crops and also highlights the value of DAS-ELISA in mass screening and development of 'Clean Stock' programme. Early detection of viruses in the propagative material is a pre-requisite for checking their effective spread and to guarantee a sustainable 'Clean Stock' programme. This programme will also help in the production of planting material of known variety and plant health status for local growers by controlling the propagation of pathogen-tested mother plants.

\section{Introduction}

Maintaining 'Clean Stock' of propagating material of temperate fruits is often considered a high risk pathway for the movement of plant pathogens particularly the graft transmissible pathogens (GTPs) including viruses, viroids and phytoplasma as these pathogens are likely to be transmitted through infected scion wood and other means of plant propagation from mother blocks and nuclear stock to the commercial growing units and individual fruit growers. Viruses and related pathogens are often associated with the fruit tree production system all over the world. While some viruses are known to have a minor impact on infected plants, other viruses can lead to long term impact on the entire propagation and fruit production system and can lead to major crop losses over a period of time. Since GTPs are integrated into the entire production chain, plants once infected with GTPs, cannot be cured. The only way to remove GTPs from a progeny orchard or nuclear stock is by destroying the infected plants and by replacing these with indexed clean plants. The present paper discusses an approach which is being used for developing a 'Clean Stock' programme for mass screening of major temperate fruit germplasm against viruses in Himachal Pradesh, India. The current system employs DAS-ELISA for screening of 
germplasm as it has been found to be a quick and reliable diagnostic tool.

The 'Clean Stock' programme described in this paper uses a systematic approach in order to produce virus indexed fruit tree nursery stock. The approach essentially involves various independent components such as virus-testing employing DAS-ELISA, regular field inspection, maintaining proper isolation distances and vector control wherein all these components are synchronised to work in tandem to minimize the presence and the spread of viruses and related pathogens. It is however very important that the 'Clean Stock' programme thus devised for the state of Himachal Pradesh should harmonize with similar programmes in the country including nursery certification scheme so that the programme can provide the nurseries involved in commercial marketing of temperate fruit plants with guidelines for a single cohesive streamlined procedure.

\section{Materials and Methods}

\section{Collection of samples}

Random samples from different cultivars of apple, pear, plum, cherry, rootstocks of pear and plum collected by the field functionaries of the Department of Horticulture, Government of Himachal Pradesh were supplied through the respective incharges of the progeny-cum-demonstration orchards (PCDO) from Shimla, Chamba, Kullu and Solan districts of Himachal Pradesh. The samples were brought to the laboratory for serological indexing against major viruses of temperate fruits. All samples were subjected to serological indexing using DAS-ELISA with antibodies against apple mosaic virus (ApMV), apple chlorotic leafspot virus (ACLSV), apple stem pitting virus (ASPV), apple stem grooving virus (ASGV) and prunus necrotic ring spot virus (PNRSV) procured from BIOREBA, Switzerland in Microscan MS 5608A ELISA plate reader from ECIL, Hyderabad, India. Additionally, samples were also collected from the Model Farm of Dr. Y S Parmar University of Horticulture and Forestry, Nauni, Solan. In all, 47 samples from different cultivars and rootstocks of temperate fruits were indexed serologically using DAS-ELISA to ascertain the sanitary status of temperate fruit planting material maintained at different PCDOs and other farms.

\section{ELISA detection}

The protocol given by Clark and Adams (1977) was followed for conducting DASELISA tests. Wells of the microtitre plate (NUNC maxisorp certified microplates) except those of the top and bottom rows and rows on the extreme left and right, were filled with $100 \mu \mathrm{l}$ aliquots of coating antibodies diluted in $1 \mathrm{X}$ coating buffer (1:500 ratio v/v). The plate was incubated in humid box for 4 hours at $37^{\circ} \mathrm{C}$. The coating antibody suspension was removed by shaking out the plate over the wash basin. The wells were filled with $1 \mathrm{X}$ PBS-Tween and kept for 2 minutes with gentle shaking. The plate was emptied and filled again with PBS-Tween. The washing was repeated three times. The test samples were ground in $1 \mathrm{X}$ extraction buffer $(1: 10$ ratio w/v). All coated wells were filled with $100 \mu \mathrm{l}$ aliquots of test sample (each sample in duplicate) besides positive and negative control wells. The plates were incubated in humid box overnight at $4 \pm 1^{\circ} \mathrm{C}$. The washing steps were repeated as mentioned above. The alkaline phosphatase (ALP) conjugate antibodies were filled in each well with $100 \mu \mathrm{l}$ aliquots after diluting it in $1 \mathrm{X}$ conjugate buffer at a ratio of 1:500 (v/v). The plate was incubated in humid box for 2 hours at $37^{\circ} \mathrm{C}$. The washing was done as mentioned above. The p-nitrophenyl phosphate (pNPP) substrate was dissolved in $1 \mathrm{X}$ substrate buffer. 
Table.1 Details of varieties and rootstocks of temperate fruits

\begin{tabular}{|c|c|c|c|c|}
\hline Sample No. & Location & District & Crop & Cultivar/rootstock \\
\hline 1 & \multirow{9}{*}{ PCDO, Chamba } & \multirow{9}{*}{ Chamba } & \multirow{9}{*}{ Apple } & Jeromine \\
\hline 2 & & & & Jeromine \\
\hline 3 & & & & Jeromine \\
\hline 4 & & & & Gale Gala \\
\hline 5 & & & & Gale Gala \\
\hline 6 & & & & Gale Gala \\
\hline 7 & & & & Auvial Early Fuji \\
\hline 8 & & & & Auvial Early Fuji \\
\hline 9 & & & & Auvial Early Fuji \\
\hline 10 & \multirow{11}{*}{ PCDO, Duttnagar } & \multirow{11}{*}{ Shimla } & \multirow{9}{*}{ Apple } & Jeromine/M-9 \\
\hline 11 & & & & Redcap Valtod/MM-106 \\
\hline 12 & & & & Super Chief/MM-106 \\
\hline 13 & & & & Redlum Gala/M-9 \\
\hline 14 & & & & Sun Fuji/M-9 \\
\hline 15 & & & & Scarlet Spur II/MM-106 \\
\hline 16 & & & & Granny Smith/M-9 \\
\hline 17 & & & & Clonal rootstock M-9 \\
\hline 18 & & & & Clonal rootstock EMLA-9 \\
\hline 19 & & & \multirow[t]{2}{*}{ Cherry } & Glory/Gisella-5 \\
\hline 20 & & & & Regina/Gisella-5 \\
\hline 21 & \multirow[t]{2}{*}{ PCDO, Bathara } & \multirow[t]{2}{*}{ Shimla } & \multirow[t]{2}{*}{ Apple } & Redlum Gala/M-9 \\
\hline 22 & & & & Scarlet Spur II/MM-106 \\
\hline 23 & PCDO, Patta Mahlog & \multirow{8}{*}{ Solan } & Pear & Rootstock BA-29 \\
\hline 24 & \multirow[t]{2}{*}{ PCDO, Darlaghat } & & \multirow[t]{2}{*}{ Plum } & Myrobalan \\
\hline 25 & & & & Pixy \\
\hline 26 & \multirow{5}{*}{$\begin{array}{l}\text { University Model Farm, } \\
\text { YSPUHF, Nauni }\end{array}$} & & \multirow{5}{*}{ Apple } & Red Velox \\
\hline 27 & & & & Modi \\
\hline 28 & & & & Buckeye Gala \\
\hline 29 & & & & Scarlet Spur III \\
\hline 30 & & & & Jeromine \\
\hline 31 & \multirow{3}{*}{$\begin{array}{l}\text { Fruit Development } \\
\text { Project, Bajaura }\end{array}$} & \multirow{3}{*}{ Kullu } & \multirow{3}{*}{ Apple } & Gale Gala/M-9 \\
\hline 32 & & & & Redlum Gala/M-9 \\
\hline 33 & & & & Granny Smith/M-9 \\
\hline 34 & \multirow[t]{2}{*}{ PCDO, Chowai } & \multirow[t]{2}{*}{ Kullu } & \multirow[t]{2}{*}{ Apple } & Redcap Valtod/MM-106 \\
\hline 35 & & & & Sun Fuji/M-9 \\
\hline 36 & \multirow{12}{*}{ PCDO Bagthan } & \multirow{12}{*}{ Sirmour } & & Redlum Gala \\
\hline 37 & & & & Sun Fuji \\
\hline 38 & & & & Gale Gala \\
\hline 39 & & & Apple & Red Fuji \\
\hline 40 & & & & Red Velox \\
\hline 41 & & & & Granny Smith \\
\hline 42 & & & & Auvial Early Fuji \\
\hline 43 & & & & Jeromine \\
\hline 44 & & & & Super Chief \\
\hline 45 & & & & Recap Valtod \\
\hline 46 & & & Pear & Carmen \\
\hline 47 & & & & Concorde \\
\hline
\end{tabular}


Table.2 DAS- ELISA detection of viruses in test samples

\begin{tabular}{|c|c|c|c|c|c|}
\hline \multirow[t]{2}{*}{ Sample No. } & \multicolumn{5}{|c|}{ O.D value $\left(\mathrm{A}_{405} \mathrm{~nm}\right) /$ reaction } \\
\hline & ApMV & ACLSV & ASGV & ASPV & PNRSV \\
\hline 1 & $0.165(-)$ & $0.182(-)$ & $0.154(-)$ & $0.185(-)$ & $0.117(-)$ \\
\hline 2 & $0.122(-)$ & $0.138(-)$ & $0.091(-)$ & $0.137(-)$ & $0.125(-)$ \\
\hline 3 & $0.139(-)$ & $0.146(-)$ & $0.134(-)$ & $0.144(-)$ & $0.114(-)$ \\
\hline 4 & $0.106(-)$ & $0.142(-)$ & $0.135(-)$ & $0.145(-)$ & $0.131(-)$ \\
\hline 5 & $0.099(-)$ & $0.124(-)$ & $0.118(-)$ & $0.125(-)$ & $0.148(-)$ \\
\hline 6 & $0.108(-)$ & $0.136(-)$ & $0.157(-)$ & $0.163(-)$ & $0.127(-)$ \\
\hline 7 & $0.123(-)$ & $0.179(-)$ & $0.259(-)$ & $0.152(-)$ & $0.146(-)$ \\
\hline 8 & $0.170(-)$ & $0.116(-)$ & $0.252(-)$ & $0.123(-)$ & $0.113(-)$ \\
\hline 9 & $0.124(-)$ & $0.121(-)$ & $0.254(-)$ & $0.129(-)$ & $0.125(-)$ \\
\hline 10 & $0.088(-)$ & $0.241(-)$ & $0.260(-)$ & $0.279(-)$ & $0.151(-)$ \\
\hline 11 & $0.158(-)$ & $0.157(-)$ & $0.196(-)$ & $0.158(-)$ & $0.145(-)$ \\
\hline 12 & $0.112(-)$ & $0.163(-)$ & $0.125(-)$ & $0.191(-)$ & $0.118(-)$ \\
\hline 13 & $0.136(-)$ & $0.130(-)$ & $0.111(-)$ & $0.146(-)$ & $0.122(-)$ \\
\hline 14 & $0.092(-)$ & $0.197(-)$ & $0.090(-)$ & $0.179(-)$ & $0.157(-)$ \\
\hline 15 & $0.130(-)$ & $0.193(-)$ & $0.141(-)$ & $0.212(-)$ & $0.114(-)$ \\
\hline 16 & $0.390(+)$ & $0.820(+)$ & $0.404(+)$ & $0.438(+)$ & $0.160(-)$ \\
\hline 17 & $0.131(-)$ & $0.135(-)$ & $0.136(-)$ & $0.170(-)$ & $0.124(-)$ \\
\hline 18 & $0.108(-)$ & $0.124(-)$ & $0.156(-)$ & $0.059(-)$ & $0.138(-)$ \\
\hline 19 & $0.144(-)$ & $0.117(-)$ & $0.108(-)$ & $0.086(-)$ & $0.154(-)$ \\
\hline 20 & $0.137(-)$ & $0.121(-)$ & $0.133(-)$ & $0.131(-)$ & $0.137(-)$ \\
\hline 21 & $0.124(-)$ & $0.236(-)$ & $0.132(-)$ & $0.115(-)$ & $0.096(-)$ \\
\hline 22 & $0.066(-)$ & $0.106(-)$ & $0.135(-)$ & $0.158(-)$ & $0.127(-)$ \\
\hline 23 & $0.095(-)$ & $0.146(-)$ & $0.188(-)$ & $0.104(-)$ & $0.118(-)$ \\
\hline 24 & $0.107(-)$ & $0.122(-)$ & $0.096(-)$ & $0.109(-)$ & $0.166(-)$ \\
\hline 25 & $0.118(-)$ & $0.238(-)$ & $0.135(-)$ & $0.141(-)$ & $0.163(-)$ \\
\hline 26 & $0.129(-)$ & $0.283(-)$ & $0.197(-)$ & $0.242(-)$ & $0.131(-)$ \\
\hline 27 & $0.135(-)$ & $0.187(-)$ & $0.163(-)$ & $0.161(-)$ & $0.112(-)$ \\
\hline 28 & $0.149(-)$ & $0.106(-)$ & $0.106(-)$ & $0.182(-)$ & $0.086(-)$ \\
\hline 29 & $0.093(-)$ & $0.112(-)$ & $0.186(-)$ & $0.124(-)$ & $0.119(-)$ \\
\hline 30 & $0.171(-)$ & $0.262(-)$ & $0.194(-)$ & $0.246(-)$ & $0.134(-)$ \\
\hline 31 & $0.130(-)$ & $0.163(-)$ & $0.186(-)$ & $0.145(-)$ & $0.122(-)$ \\
\hline 32 & $0.146(-)$ & $0.132(-)$ & $0.172(-)$ & $0.153(-)$ & $0.108(-)$ \\
\hline 33 & $0.151(-)$ & $0.131(-)$ & $0.188(-)$ & $0.151(-)$ & $0.112(-)$ \\
\hline 34 & $0.125(-)$ & $0.148(-)$ & $0.131(-)$ & $0.109(-)$ & $0.111(-)$ \\
\hline 35 & $0.150(-)$ & $0.165(-)$ & $0.144(-)$ & $0.136(-)$ & $0.139(-)$ \\
\hline 36 & $0.137(-)$ & $0.154(-)$ & $0.212(-)$ & $0.149(-)$ & $0.206(-)$ \\
\hline 37 & $0.127(-)$ & $0.156(-)$ & $0.219(-)$ & $0.149(-)$ & $0.115(-)$ \\
\hline 38 & $0.079(-)$ & $0.174(-)$ & $0.132(-)$ & $0.153(-)$ & $0.090(-)$ \\
\hline 39 & $0.104(-)$ & $0.151(-)$ & $0.145(-)$ & $0.116(-)$ & $0.134(-)$ \\
\hline 40 & $0.131(-)$ & $0.163(-)$ & $0.216(-)$ & $0.103(-)$ & $0.167(-)$ \\
\hline 41 & $0.096(-)$ & $0.159(-)$ & $0.121(-)$ & $0.132(-)$ & $0.138(-)$ \\
\hline 42 & $0.141(-)$ & $0.151(-)$ & $0.172(-)$ & $0.126(-)$ & $0.140(-)$ \\
\hline 43 & $0.152(-)$ & $0.167(-)$ & $0.156(-)$ & $0.159(-)$ & $0.153(-)$ \\
\hline 44 & $0.163(-)$ & $0.154(-)$ & $0.126(-)$ & $0.144(-)$ & $0.142(-)$ \\
\hline 45 & $0.148(-)$ & $0.201(-)$ & $0.183(-)$ & $0.169(-)$ & $0.177(-)$ \\
\hline 46 & $0.096(-)$ & $0.237(-)$ & $0.200(-)$ & $0.183(-)$ & $0.162(-)$ \\
\hline 47 & $0.110(-)$ & $0.252(-)$ & $0.189(-)$ & $0.176(-)$ & $0.153(-)$ \\
\hline
\end{tabular}


Each well was filled with $100 \mu$ l aliquots of substrate. The plates were kept in humid box in dark condition at room temperature until a yellow colour was clearly visible in the positive control (usually between 30 to 60 minutes). If desired, the reaction was stopped by adding $50 \mu \mathrm{l}$ of $3 \mathrm{M} \mathrm{NaOH}$ to each well.

\section{Results and Discussion}

A total of 47 samples were collected from different locations in five districts of Himachal Pradesh and serologically indexed for the possible association of major viruses of temperate fruits to identify the infected plants, if any. The details of the samples tested in respect of different crops and their varieties and rootstocks are listed in Table 1.

Results of DAS-ELISA tests conducted on the test samples presented in Table 2 clearly indicate that out of 47 test samples of apple, pear, plum, cherry and rootstocks only one sample (sample No. 16) of apple variety Granny Smith representing PCDO Duttnagar in Shimla district tested positive against antibodies of ApMV, ACLSV, APSV and ASGV with O.D. values of $0.390,0.820$, 0.404 and 0.438 , respectively. All other samples were found to be free from infection of all five major viruses considered for the studies. Systematic studies conducted on the detection of viruses in temperate fruits in different parts of the world have revealed the presence of one or more of these viruses either alone or in combination in apple and other temperate fruits (Polak, 2008; Rovira and Aramburu, 1998; Ylmaz et al., 2005; Birisik et al., 2008; Svoboda and Polak, 2008; Menzel et al., 2003; Boulila and Marrakchi, 2001; Chandel et al., 2008; Kapoor and Handa; 2017; Sanchez-Perez et al., 2017).

Use of DAS- ELISA as a diagnostic tool for quick and reliable detection of viruses in planting material of temperate fruits in these studies has been found to be a highly efficient and effective approach as a step forward for developing 'Clean Stock' programme in Himachal Pradesh. A programme thus developed will pave the way for producing healthy planting material in other temperate fruit growing states of India that will eventually benefit the farming community as a whole.

\section{References}

Birisik N, Myrta A, Hassan M and Baloglu S. 2008. A preliminary account on apple viruses in Mediterranean Region of Turkey. Acta Horticulturae., 781:125130.

Boulila M and Marrakchi M. 2001. Sequence Amplification (RT-PCR) and Restriction Fragment Polymorphism (RFLP) Analysis of Some Isolates of Prunus necrotic ringspot ilarvirus. EPPO Bulletin., 31:173-178.

Chandel V, Rana T, Handa A, Thakur PD, Hallen V and Zaidi AA. 2008. Incidence of Prunus necrotic ring spot virus on Malus domestica in India. Journal of Phytopathology., 156:382384.

Clark MF and Adams AN. 1977. Characteristics of the microplate method of enzyme-linked immunosorbent assay for the detection of plant viruses. Journal of general virology., 34:475- 483.

Kapoor S and Handa A. 2017. Prevalence of PNRSV in Peach orchards of Himachal Pradesh and its detection through DASELISA. Journal of Plant Diseases Sciences., 12:129-132.

Menzel W, Zahn V and Maiss E. 2003. Multiplex RT-PCR-ELISA compared with bioassay for the detection of four apple viruses. Journal of Virological Methods., 110:153-157. 
Polak J, Hassan M, and Paprstein F. 2008. Detection and distribution of four pome fruit viruses in germplasm collection in the Czech Republic. Acta Horticulturae., 781:113-118.

Rovira M and Aramburu J. 1998. Incidence of Apple mosaic virus (ApMV) disease on hazelnut (Corylus avellana L.) in Spain and its effects on yield. Nucis Newsletter., 7: 18-20.

Sanchez RP, Morales-Corts MR. and Sanchez MAG. 2017. Sour and duke Cherry viruses in South-West Europe.
Phytopathologia Mediterranea., 56:6269.

Svoboda J and Polak J. 2010. Relative concentration of apple mosaic virus coat protein in different parts of apple tree. Horticultural Science., 37: 22-26.

Ylmaz ND, Yanar Y, Kadoglu I and Yanar D. 2005. Study on distribution of apple mosaic virus (ApMV) in apple orchards in Tokat Province. Ondokuz Mays Universitesi Ziraat Fakultesi Dergisi., 20:12-15.

\section{How to cite this article:}

Anil Handa and Shelly Kapoor. 2018. Mass Screening of Temperate Fruit Germplasm against Major Viruses for developing a 'Clean Stock' Programme in Himachal Pradesh, India. Int.J.Curr.Microbiol.App.Sci. 7(06): 679-684. doi: https://doi.org/10.20546/ijcmas.2018.706.079 